\title{
РЕЗУЛЬТАТИ ЕКСПЕРИМЕНТАЛЬНОГО ДОСЛІДЖЕННЯ МЕТОДУ АКТИВНОГО УПРАВЛІННЯ ЧЕРГАМИ НА ІНТЕРФЕЙСАХ ТЕЛЕКОМУНІКАЦІЙНИХ МЕРЕЖ
}

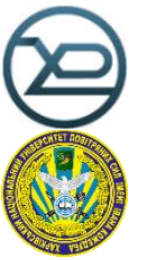

\author{
Т.М. ЛЕБЕДЕНКО \\ Харківський націюнальний університет радіоелектроніки \\ $\underline{\text { M.В. ГОАОВЕШКО, A.В. СЕВЕРІАОВ }}$ \\ Харківський національний університет повітряних сил імені Івана Кожедуба
}

\begin{abstract}
The paper presents the results of an experimental study of the active queue management method at the interfaces of telecommunication networks. Experimental adequacy and assessment of the effectiveness of the method from the point of view of the main quality of services indicators were carried out at the base of the Cisco Systems laboratory. As a load testing package, the D-ITG package was used to generate and further analyze network traffic. In order to verify the interface bandwidth allocation solutions obtained during the application of the method, they were compared with the WFQ scheduling mechanisms for the average packet delay. To verify the obtained solutions using the active queue management method, they were compared with the AQM WRED mechanisms according to the probability of packet loss. The results of the investigation confirmed the effectiveness of the active queue management method in terms of improving the average packet delay - from 12-17\% to 22-25\% for high-priority flows (EF, AF41-43) and from 8-12\% to 16-19\% for low priority flows (AF11-13). Using the active queue management method reduced the probability of packet loss by 7 $12 \%$ for high-priority flows (EF, AF41-43) and by 10-17\% for low-priority flows (AF11-13). It has been established that the recommended area of the practical application of the proposed models for queuing and bandwidth management is the areas of high congestion (more than 80-85\%) and congestion of interfaces of telecommunication networks routers, especially in conditions of increased dynamics of their state change.
\end{abstract}

Анотація - У роботі представлено результати експериментального дослідження методу активного управління чергами на інтерфейсах телекомунікаційних мереж. Експериментальне дослідження адекватності та оцінка ефективності методу з точки зору основних показників якості обслуговування проводилося на базі лабораторії компанії Cisco Systems. Як пакет навантажувального тестування для генерування та подальшого аналізування мережного трафіка використовувався пакет D-ITG. Для перевірки отриманих у ході застосування методу рімень щодо розподілу пропускної здатності інтерфейсу проводилося їхне порівняння з механізмами планування WFQ за середньою затримкою пакетів, а рімень щодо активного управління чергами - порівняння з механізмами AQM WRED за ймовірністю втрат пакетів. Результати проведеного дослідження підтвердили ефективність методу активного управління чергами з точки зору покращення середньої затримки пакетів - від 12-17\% до 22-25\% для високопріоритетних потоків (EF, AF41-43) та ві 8-12\% до 16-19\% - для низькопріоритетних потоків (AF11-13). Використання методу активного управління чергами дозволило знизити ймовірність втрат пакетів на 7-12\% для високопріоритетних потоків (ЕF, АF41-43) та на 10-17\% - для низькопріоритетних потоків (АF11-13). Установлено, що рекомендована область практичного застосування пропонованих моделей управління чергами та пропускною здатністю - області високої завантаженості (більще 80-85\%) та перевантаження інтерфейсів марирутизаторів ТКМ, особливо в уловах підвищеної динаміки зміни їхнього стану.

\section{Вступ}

Важливим етапом удосконалення існуючих або розробки нових методів управління чергами на інтерфейсах маршрутизаторів телекомунікаційних мереж (TKM) є організація і проведення їх експериментадьного дослідження. Відомо, що використання засобів аналітичного моделювання, як правило, не затратне за часом та дозволяе дослідити мережні процеси для досить широкої множини вихідних даних: характеристик трафіка, параметрів інтерфейсу, дисциплін обслуговування тощо. 
Проте для підвищення адекватності та точності результатів дослідження аналітичні розрахунки обов'язково мають бути доповнені в ході натурного (дабораторного) експерименту на реальному мережному обладнанні [1-3].

Проведення лабораторного (натурного) експерименту грунтується на вирішенні таких важдивих завдань:

- розробка загадьної схеми проведення експерименту щодо активного управління чергами на інтерфейсах маршрутизаторів телекомунікаційних мереж та опис їі структури;

- огляд та вибір засобів навантажувального тестування та аналізу мережного трафіка;

- опис фрагмента мережі та порядку налаштування мережних інтерфейсів під вирішення задач управління чергами;

- аналіз отриманих у ході проведення лабораторного експерименту результатів;

- розробка та обгрунтування рекомендацій щодо областей найбільш ефективного практичного застосування досліджених методів управління чергами.

У даній роботі об'єктом дослідження обрано метод активного управдіння чергами на інтерфейсах маршрутизаторів ТКМ, який описано в роботах [4-8]. Основу цього методу складають такі моделі:

- модель оптимадьного агрегування та розподілу потоків пакетів між чергами;

- модель збалансованого розподілу пропускної здатності інтерфейсу маршрутизатора ТКМ між сформованими класовими чергами;

- модель активного управління чергами на інтерфейсах маршрутизаторів ТКМ, які будуть описані нижче.

\section{I. Модель оптимального агрегування та розподілу потоків пакетів між чергами інтерфейсів маршрутизаторів телекомунікаційних мереж}

Як показано в роботах [4-6], в основу моделі оптимального агрегування та розподілу потоків пакетів між чергами інтерфейсів маршрутизаторів телекомунікаційних мереж покладено розв'язання оптимізаційної задачі лінійного цілочисельного програмування з критерієм оптимальності:

$$
\min _{x} F, F=\sum_{i=1}^{N} \sum_{j=1}^{M} h_{i, j}^{x} x_{i, j},
$$

де

$$
x_{i, j} \in\{0 ; 1\}
$$

- керуючі змінні, кожна з яких характеризуе частку $i$-го потоку пакетів, спрямованого на обслуговування до j-ї черги; $N$ - загальна кількість потоків пакетів, що надходять на обраний інтерфейс відповідно до змісту маршрутної таблиці на маршрутизаторі 
TKM; $M$ - число організованих черг на інтерфейсі маршрутизатора; $h_{i, j}^{x}$ - умовна вартість (метрика) обслуговування пакетів $i$-го потоку $j$-ю чергою [4-6]:

$$
h_{i, j}^{x}=\left(k_{i}^{f}-k_{j}^{q}\right)^{2}+1
$$

Відповідно до фізичного змісту задачі, що підлягає розв'язанню, метрика $h_{i, j}^{x}$ буде мінімальною, тобто дорівнюватиме одиниці, у випадку співпадіння класів $k_{i}^{f}$ та $k_{j}^{q}$. Чим більша різниця у значеннях класів потоку та черги, тим метрика (3) буде більшою, що стримуватиме направлення потоків різних класів до однієї класової черги в ході розв'язання оптимізаційної задачі (1) при наявності обмежень (1).

\section{II. Модель збалансованого розподілу пропускної здатності інтерфейсу між сформованими класовими чергами}

У межах методу управління чергами, який підлягає дослідженню, після розв'язання задачі агрегування та розподілу потоків пакетів між чергами здійснюеться розподіл між ними пропускної здатності інтерфейсу маршрутизатора TКМ. Для цього вводиться множина керуючих змінних $b_{j}$, кожна з яких визначає частку пропускної здатності інтерфейсу, виділену для обслуговування $j$-ї черги [4-6]. Для адекватного розподілу загальної пропускної здатності інтерфейсу $b$ між створеними на ньому чергами на введені керуючі змінні накладаються такі обмеження:

$$
b_{j} \geq 0, \quad \sum_{j=1}^{M} b_{j} \leq b, \quad(j=\overline{1, M}) .
$$

3 метою забезпечення збалансованого розподілу пропускної здатності інтерфейсу між сформованими на ньому класовими чергами в структуру моделі вводяться умови запобігання перевантаження черг за пропускною здатністю, що їм виділена [5]:

$$
\alpha \sum_{i=1}^{*} a_{i} x_{i, j} \leq h_{j}^{\alpha} b_{j},(j=\overline{1, M}),
$$

де $a_{i}(i=\overline{1, N})$ - середня інтенсивність $i$-го потоку, яка вимірюється в пакетах за секунду $(1 / \mathrm{c}) ; \alpha^{*}$ - додатково введена керуюча змінна, яка обернено пропорційна до верхнього порогу завантаженості черг інтерфейсу $(\alpha)$, тобто:

$$
\alpha^{*}=\frac{1}{\alpha} \text {. }
$$

На цю змінну накладаються такі обмеження [5]:

$$
\alpha^{*}>0 \text {. }
$$


У виразі (5) $h_{j}^{\alpha}-$ класовий коефіцієнт, який введено 3 метою врахування класів черг при балансуванні розподілу пропускної здатності інтерфейсу між чергами:

$$
h_{j}^{\alpha}=1+\frac{k_{j}^{q}}{K \cdot D},(j=\overline{1, M}),
$$

де $D \geq 1$ - коефіцієнт нормування, за допомогою якого здійснюється диференціація розподілу пропускної здатності інтерфейсу маршрутизатора між організованими на ньому класовими чергами. Чим вище значення $D$, тим менше впливатиме клас черги $k_{j}^{q}$ на об'єм виділеної ій пропускної здатності інтерфейсу.

Тоді в основу моделі збалансованого розподілу пропускної здатності інтерфейсу між сформованими класовими чергами покладається розв' язання оптимізаційної задачі лінійного програмування з критерієм оптимальності

$$
\max _{b, \alpha^{*}} \alpha^{*}
$$

при наявності обмежень (4)-(7), коли $x_{i, j}$ є відомими значеннями, які отримані в ході попереднього розв'язання задачі (1)-(3).

\section{III. Модель активного управління чергами на інтерфейсах маршрутизаторів ТКМ}

У разі перевантаження інтерфейсу, коли пропускної здатності інтерфейсу не вистачає для обслуговування потоків, які на нього надходять, забезпечити виконання умови (5) немождиво. Тоді замість моделі (4)-(8) варто використовувати модель активного управління чергами на інтерфейсах маршрутизаторів ТКМ [4-6], яка орієнтує на погоджене розв'язання задач розподілу пропускної здатності інтерфейсу та превентивного (завчасного) обмеження інтенсивності потоків, що надходять на вхід цього ж інтерфейсу маршрутизатора ТКМ.

Для вирішення цих задач за аналогією з моделдю збалансованого розподілу пропускної здатності інтерфейсу вводиться множина керуючих змінних $b_{j}(j=\overline{1, M})$, які підпорядковуються умовам (4). 3 метою реалізації превентивного (завчасного) обмеження інтенсивності потоків, що надходять на вхід інтерфейса маршрутизатора ТКМ визначається множина керуючих змінних $y_{i}$, які характеризують частку $i$-го $(i=\overline{1, N})$ потоку пакетів, що отримала відмову в обслуговуванні на інтерфейсі маршрутизатора ТКМ у ході вирішення задачі активного управління чергами.

Фактично змінні $y_{i}$ визначатимуть ймовірність відкидання пакетів $i$-го потоку зі сформованої на інтерфейсі черги та підпорядковуватимуться таким умовам [4-6]:

$$
0 \leq y_{i} \leq 1, \quad(i=\overline{1, N})
$$


Для забезпечення керованості процесом активного управління чергами варто задоводьнити систему обмежень [4-6]:

$$
\sum_{i=1}^{N} a_{i} x_{i, j}\left(1-y_{i}\right) \leq b_{j}, \quad(j=\overline{1, M}) .
$$

Спираючись на сформульовані умови та обмеження (4), (9)-(10), оптимізаційна задача щодо активного управдіння чергами представлена критерієм оптимальності [4-6]:

$$
\min _{b, y} P, \quad P=\sum_{j=1}^{M} h_{j}^{b} b_{j}+\sum_{i=1}^{N} h_{i}^{y} a_{i} y_{i},
$$

де $h_{j}^{b}$ - метрика, яка характеризує умовну вартість виділення одиниці пропускної здатності інтерфейсу маршрутизатора $j$-й черзі; $h_{i}^{y}$ - метрика, яка визначає умовну вартість відмов в обслуговуванні пакетам $i$-го потоку.

Використання критерію оптимальності (11) пов'язано, по-перше, з мінімізацією використання пропускної здатності інтерфейсу маршрутизатора на підставі їі оптимадьного розподілу між сформованими чергами, а по-друге, з мінімізацією можливих відмов в обслуговуванні, викликаних превентивним обмеженням інтенсивності потоків пакетів. Метрики $h_{j}^{b}$ та $h_{j}^{b}$ напряму залежать від відповідних значень класів черг і потоків.

\section{IV. Розробка та загальний опис схеми лабораторного експерименту}

Для організації лабораторного експерименту щодо дослідження описаного вище методу активного управління чергами застосовувалась методика досліджень 3 використанням мережного обладнання виробництва компанії Cisco Systems та пакету навантажувального тестування для генерування, а також подальшого аналізу мережного трафіка [1-3, 9]. У рамках проведення лабораторного експерименту, процеси управління чергами та пропускною здатністю досліджувалися на одному високошвидкісному інтерфейсі Fast Ethernet маршрутизатора Cisco Systems cepiï 2801 3 пропускною здатністю 10/100 Мбіт/с. Стороною-відправником трафіку виступав термінал РC1, стороною-отримувачем - термінал РС2. Взаємодія кінцевих станцій здійснювалася через ділянку мережі, яка була представлена маршрутизатором Router1. Як кінцеві станції використовувалися стандартні персональні комп'ютери, підключені до маршрутизатора Router1 за допомогою технологіi Fast Ethernet. Приклад технологічної схеми підключення зображено на рис. 1. 


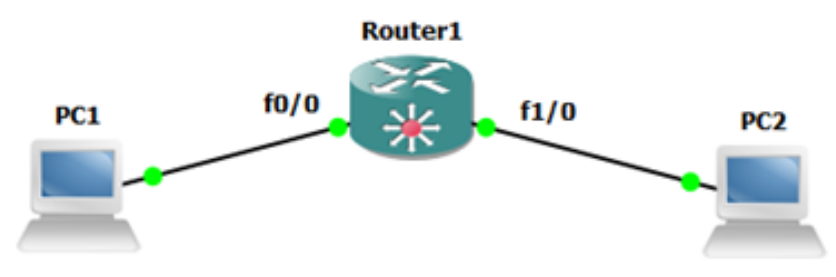

Рuc. 1. Варіант схеми підключення маршрутизатора та терміналів при проведенні лабораторного експерименту

Також за допомогою команд class проводилося налаштування механізмів управління перевантаженням, наприклад, механізму зваженого справедливого обслуговування на основі класів CBWFQ (рис. 2). В рамках наведеного прикладу було створено два класи - class1 та class2, критерієм класифікації яких виступали коди поля DSCP у заголовку IP-пакета $[1-3,9]$. Класу class 1 відповідали потоки пакетів із кодом поля DSCP AF13, тоді як класу class2 - DSCP EF. Командою bandwidth у явному вигляді ддя кожного класу задавалася пропускна здатність інтерфейсу, виділена для кожної зі сформованих на ньому черг (рис. 2 а) - класам class1 та class 2 було виділено 40 Кбіт/с та 3500 Кбіт/с відповідно.

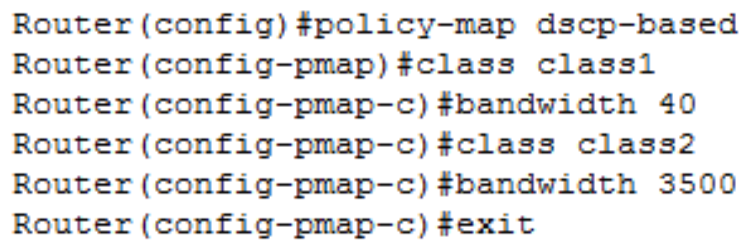

a)

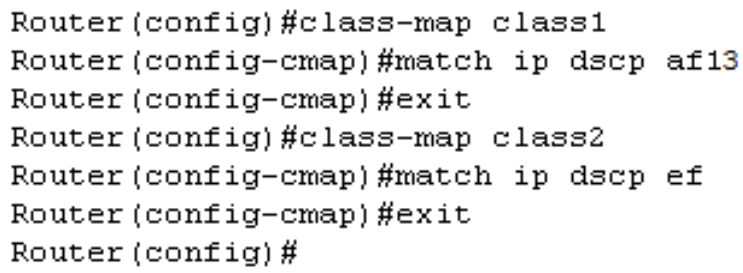

б)

Puс. 2. Приклад налаштування механізму управління перевантаженням (зваженого справедливого обслуговування на основі класів CBWFQ)

На рис. 2 б показано приклад класифікації та агрегування потоків пакетів відповідно до значення коду подя DSCP AF13 та EF у ході створення зазначених на рис. 2 а двох класів обслуговування - class 1 та class2.

Після проведених налаштувань для генерування трафіку та контролю за кількісними значеннями основних показників якості обслуговування на кінцевих станціях абонентів PC1 та РC2 необхідним є використання пакету навантажувального тестування [1-3, 9]. У загальному випадку пакети навантажувадьного тестування відносяться до засобів імітаційного моделювання, відмінними рисами яких є умови діцензування, кількість підтримуваних функцій, застосовність до різних видів операційних систем, використання різних типів протоколів і можливостей їхніх налаштувань. На сьогодні для генерації та аналізу трафіку в сучасних ТКМ широко використовуються наступні пакети: IxChariot, IPerf, IPerf3, NetPerf, D-ITG (Distributed Internet Traffic Generator), MTools, UDP-Generator, Mgen, IP Traffic, Rude/Crude. B 
табл. 1 наведено стислу характеристику та порівняння найчастіше застосовуваних при вирішенні задач управління трафіком пакетів навантажувадьного тестування [1-3, 9].

Таблиця 1. Порівняння та характеристика пакетів навантажувального тестування

\begin{tabular}{|c|c|c|c|c|}
\hline \multirow{2}{*}{$\begin{array}{c}\text { Стисла } \\
\text { характеристика }\end{array}$} & \multicolumn{4}{|c|}{ Пакет навантажувального тестування } \\
\hline & IxChariot & IPerf & NetPerf & D-ITG \\
\hline $\begin{array}{l}\text { Операційна } \\
\text { система }\end{array}$ & $\begin{array}{l}\text { Linux, } \\
\text { Windows, } \\
\text { MAC } \\
\text { Solaris, } \\
\text { Android, } \\
\text { iOS }\end{array}$ & $\begin{array}{l}\text { Linux, } \\
\text { Windows, } \\
\text { MAC OS }\end{array}$ & $\begin{array}{l}\text { Linux, } \\
\text { Windows, } \\
\text { MAC OS }\end{array}$ & $\begin{array}{l}\text { Linux, } \\
\text { Windows, } \\
\text { MAC OS X } \\
\text { (Leopard), } \\
\text { FreeBSD, } \\
\text { Android, } \\
\text { iOS }\end{array}$ \\
\hline $\begin{array}{l}\text { Вигляд } \\
\text { інтерфейсу }\end{array}$ & $\begin{array}{l}\text { Графічний } \\
\text { інтерфейс }\end{array}$ & $\begin{array}{l}\text { Командний } \\
\text { рядок }\end{array}$ & $\begin{array}{l}\text { Командний } \\
\text { рядок }\end{array}$ & $\begin{array}{l}\text { Командний } \\
\text { рядок / } \\
\text { графічний } \\
\text { інтерфейс }\end{array}$ \\
\hline $\begin{array}{l}\text { Підтримувані } \\
\text { протоколи }\end{array}$ & $\begin{array}{l}\text { TCP, UDP, RDP, } \\
\text { VoIP, IPv4, IPv6 }\end{array}$ & $\begin{array}{l}\text { TCP, UDP, } \\
\text { IPv4, IPv6 }\end{array}$ & $\begin{array}{l}\text { TCP, UDP, } \\
\text { SCTP, DLPI, } \\
\text { IPv4, IPv6 }\end{array}$ & $\begin{array}{lr}\text { TCP, } & \text { UDP, } \\
\text { ICMP, DCCP, } \\
\text { SCTP, VoIP, } \\
\text { IPv4, IPv6 }\end{array}$ \\
\hline QoS-показники & $\begin{array}{l}\text { Пропускна } \\
\text { здатність, } \\
\text { джитер, } \\
\text { кількість } \\
\text { втрачених } \\
\text { пакетів, } \\
\text { затримки } \\
\text { пакетів, MOS, } \\
\text { R-фактор }\end{array}$ & $\begin{array}{l}\text { Пропускна } \\
\text { здатність, } \\
\text { джитер, } \\
\text { кількість } \\
\text { втрачених } \\
\text { пакетів }\end{array}$ & $\begin{array}{l}\text { Пропускна } \\
\text { здатність, } \\
\text { джитер, } \\
\text { кількість } \\
\text { втрачених } \\
\text { пакетів }\end{array}$ & $\begin{array}{l}\text { Пропускна } \\
\text { здатність, } \\
\text { джитер, } \\
\text { бітрейт, } \\
\text { кідькість } \\
\text { втрачених } \\
\text { пакетів, } \\
\text { RTT, } \\
\text { затримки } \\
\text { пакетів } \\
\end{array}$ \\
\hline Посібник & Так & Так & Так & Так \\
\hline $\begin{array}{l}\text { Вільне } \\
\text { програмне } \\
\text { забезпечення } \\
\end{array}$ & $\mathrm{Hi}$ & Так & Так & Так \\
\hline
\end{tabular}

Результат проведеного аналізу показав, що найбільш коректними, зручними у використанні та наочними при дослідженні процесів управління чергами на інтерфейсах маршрутизаторів телекомунікаційних мереж $є$ пакети навантажувального тестування IxChariot та D-ITG. Дані пакети забезпечують підтримку великої кількості параметрів трафіка. Зокрема, пакет D-ITG здатен генерувати трафік із різними видами розподілу навантаження (рівномірним, детермінованим, експоненціальним, Парето, Коші, нормальним, Пуасонівським, 
гамма-розподілом, Вейбула); підтримувати протоколи мережного рівня (IPv4 i IPv6), транспортного рівня (TCP, UDP, ICMP, DCCP, SCTP) та прикладного рівня (VoIP (G.711, G.723, G.729), DNS, Telnet); працювати на операційних системах Linux, Windows, MAC OS X (Leopard), FreeBSD, Android, iOS; забезпечувати високу швидкість передачі пакетів між відправником та отримувачем (до 612 Мбіт/с). Окрім того, D-ITG дозволяє вимірювати та аналізувати величину бітрейту (bitrate), пакетної швидкості (packet rate), затримки передачі пакетів у напрямку із початку в кінець (one way delay, OWD), часу передачі пакетів у напрямку із початку в кінець і назад (round trip time, RTT), а також визначати пропускну здатність (throughput), джитер (jitter) та кількість втрачених пакетів (packet loss) [1-3, 9]. Додатковою перевагою D-ITG також є наявність вільного програмного забезпечення.

За допомогою пакета навантажувального тестування D-ITG на стороні відправника запускалася підпрограма ITGSend, в якій за допомогою керуючих параметрів (ключів) задавалися як кількість потоків пакетів, так і їхні характеристики (рис. 3).

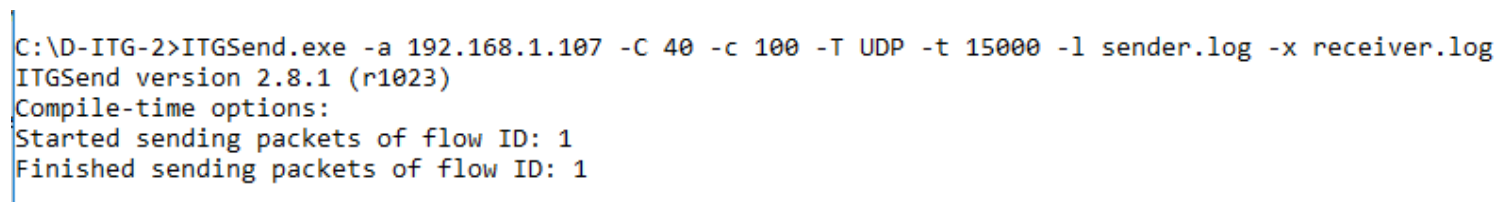

Puc. 3. Приклад налаштування підпрограми відправника пакетів ITGSend

Відповідно до прикладу, наведеного на рис. 4, відправник пакетів ITGSend має наступні характеристики потоку:

- адреса приймальної сторони (-а 192.168.1.107);

- пакетна швидкість передачі (пак/с) (-C 40);

- розмір кожного пакету (Байт) (-с 100);

- тип протоколу транспортного рівня (-T UDP);

- тривалість генерації експерименту (мс) (-t 15000);

- ім'я файлів, в які заноситимуться отримані дані, будуть створюватися як на стороні відправника (-1 sender.log), так i на стороні отримувача (-x receiver.log).

На приймальній стороні за допомогою підпрограм ITGRecv та ITGDec оброблялися та формувалися результати проведеного лабораторного експерименту відповідно до характеристик потоків зазначених на рис. 3.

Приклад декодування файлу логів (receiver.log) із відображенням значень загального числа переданих пакетів, часу проведення експерименту, а також основних показників якості обслуговування QoS (значень мінімальної, максимальної та середньої затримки пакетів, джитера, середньої бітової та пакетної швидкостей передачі, а також відсотка втрачених пакетів) представлено на рис. 4. 


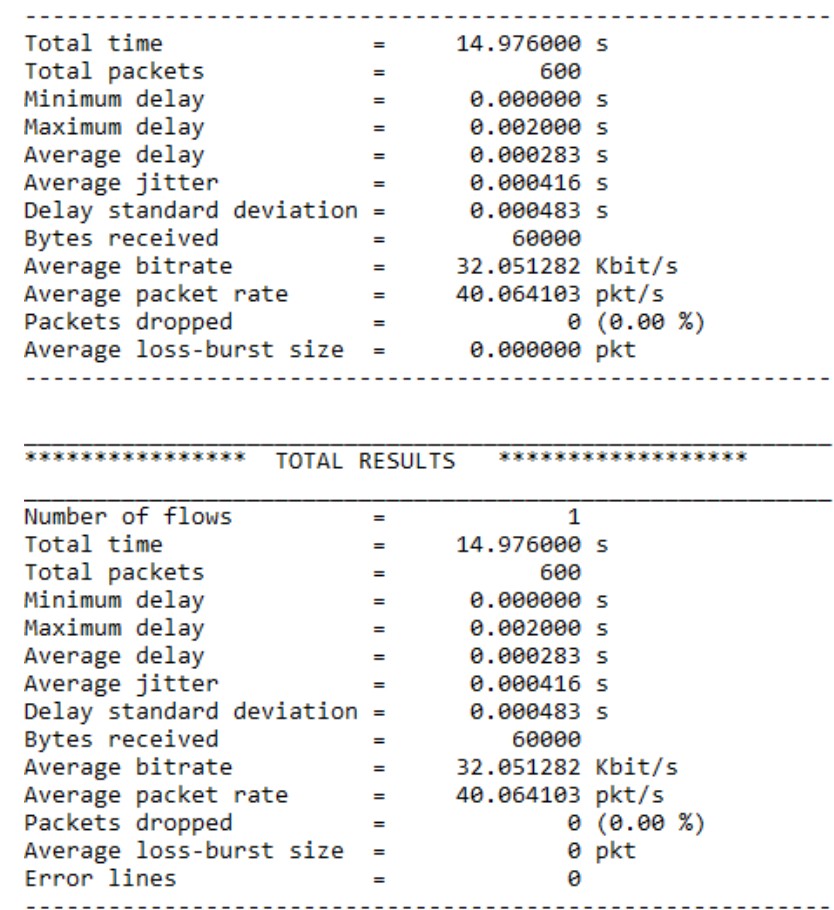

Puc. 4. Приклад відображення основних QoS-показників за допомогою пакета D-ITG

На рис. 5 наведено приклад генерації трафіка з характеристиками VoIP:

- тип використовуваних кодеків (G. 711.2 та G. 729.2);

- кількість сформованих потоків (один потік для трафіка VoIP G. 711.2 та один потік для трафіка VoIP G. 729.2);

- порт отримувач для потоку G. 711.2 - 8001;

- порт отримувач для потоку G. G. 729.2 - 8002;

- пакетна швидкість передачі (50 1/c);

- підопція VAD (включення виявлення голосової активності VoIP).

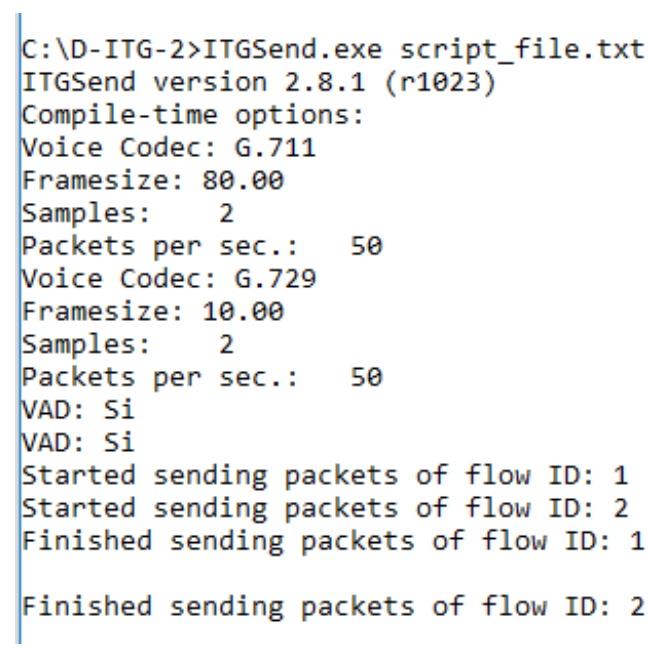

Puc. 5. Приклад налаштування підпрограми відправника пакетів ITGSend при генерації трафіка з характеристиками VoIP 
Зважаючи на багатопотоковий режим, для генерації трафіка було сформовано сценарій, описаний у текстовому файлі script_file.txt. Аналогічно прикладу, наведеному на рис. 4, для відображення значень основних показників якості обслуговування було проведено декодування створеного лог-файлу (рис. 6).

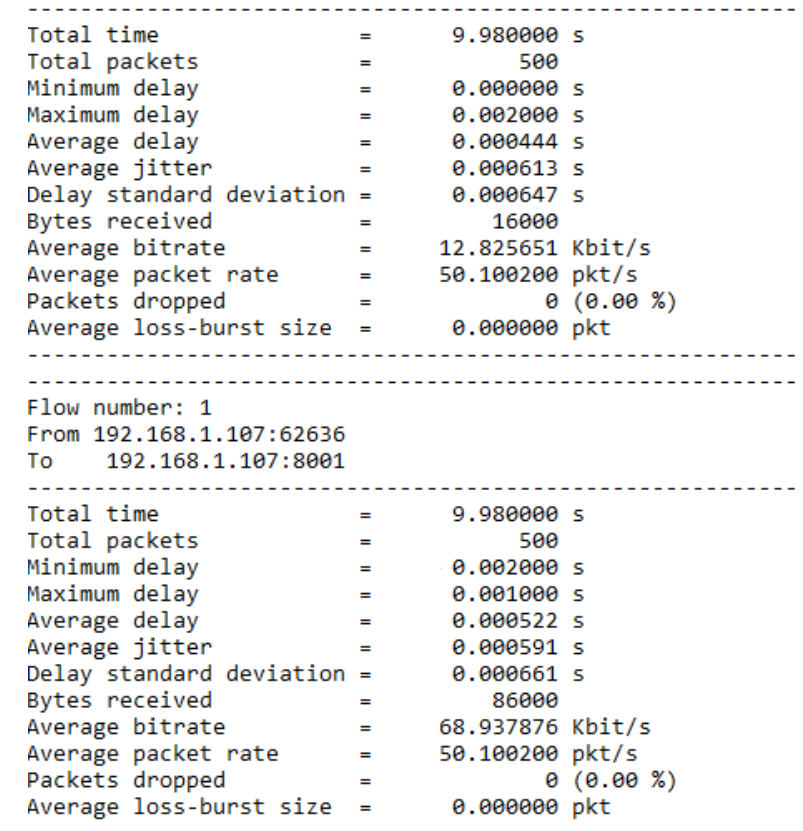

Puc. 6. Приклад відображення основних QoS-показників за допомогою пакета D-ITG при генерації трафіка з характеристиками VoIP

\section{V. Результати експериментального дослідження та оцінка ефективності досліджуваного методу активного управління чергами}

На основі розглянутої методики було проведено ряд лабораторних експериментів щодо дослідження процесів активного управління чергами на інтерфейсі маршрутизатора ТКМ. Для оцінки ефективності запропонованих моделей порівнювалися результати їхньої роботи (за основними показниками якості обслуговування) 3 технологічними рішеннями механізмів управління перевантаженнями - WFQ та запобігання перевантаженням - WRED, які були налаштовані на інтерфейсах маршрутизаторів автоматично. Зокрема, отримані результати порівнювалися за показниками середньої затримки пакетів та ймовірністю втрат пакетів. Зміні підлягали: пропускна здатність інтерфейсу; кількість потоків пакетів, що надходили на його вхід; значення класів потоків та інтенсивностей; кількість сформованих на інтерфейсі черг та їхня класифікація.

Для прикладу, нехай на інтерфейс маршрутизатора ТКМ надходив агрегований трафік, в якому кількість потоків пакетів змінювалася від одного до двадцяти. Диференціація потоків здійснювалася на основі змісту коду поля диференційованих послуг DSCP у заголовку IP-пакета. Тоді потокам голосового трафіка VoIP ставився у відповідність код подя (пріоритет) ЕF, потокам інтерактивного відео (відеоконференцій) та аудіо/відео за запитом - AF41, потокам критично важдивих 
даних - AF31, потокам передачі даних - AF13. Кожний потік обслуговувався в рамках окремо сформованих черг.

На рис. 7 - рис. 10 наведено результати порівнянь рішень, отриманих у ході проведення лабораторного експерименту щодо впливу завантаженості інтерфейсу маршрутизатора на середню затримку пакетів для запропонованої моделі збалансованого розподілу пропускної здатності інтерфейсу ТКМ (1)-(8), та ддя механізмів WFQ/WRED, налаштованих на інтерфейсі маршрутизатора «за замовчуванням». Завантаженість інтерфейсу $(\rho)$ визначалася як відношення сумарного пакетного навантаження на інтерфейс маршрутизатора телекомунікаційної мережі до його пропускної здатності. Так, на рис. 7 наведено результати дослідження, коли структура трафіка є симетричною, тобто кількість потоків пакетів, що надходить до сформованих на інтерфейсі маршрутизатора телекомунікаційної мережі класових черг, є однаковою: по чотири потоки на кожну чергу.

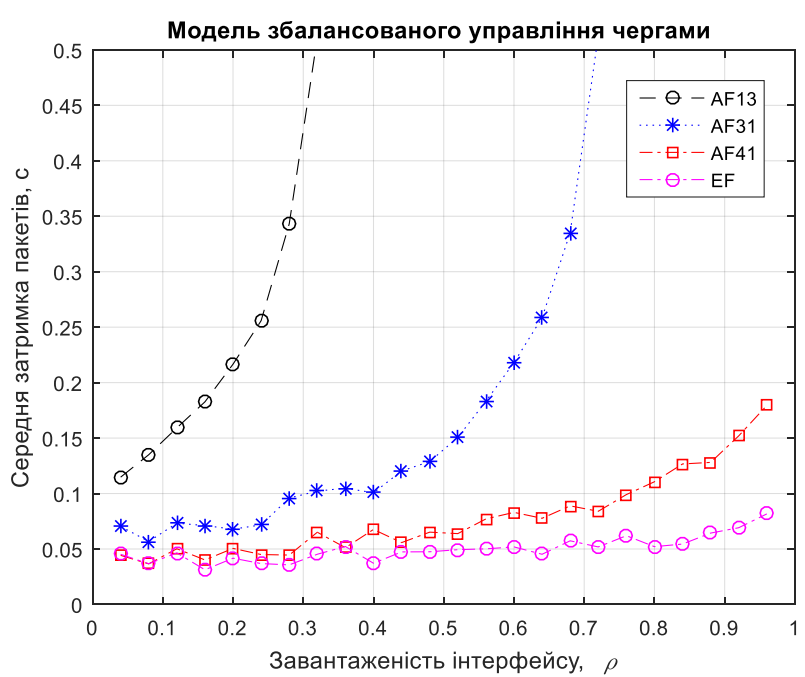

a)

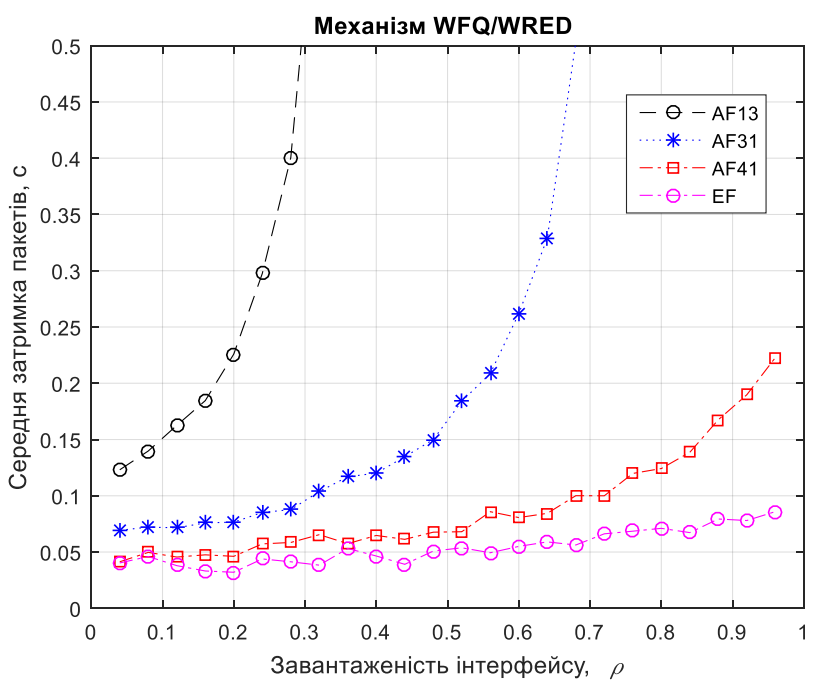

б)

Рuc. 7. Аналіз впливу завантаженості інтерфейсу на середню затримку пакетів при генерації симетричного трафіка з різними значеннями поля DSCP для моделі збалансованого управління (а) та механізму WFQ/WRED (б)

Аналіз отриманих рішень щодо впливу завантаженості інтерфейсу на середню затримку пакетів (рис. 7) показав, що в умовах генерації симетричного трафіка 3 різними значеннями коду поля DSCP обидва рішення працюють адекватно, виділяючи кожній з черг пропускну здатність інтерфейсу відповідно до значення іï класу. Проте запропонована модель збалансованого управління чергами (на відміну від механізму WFQ) дозволяє за необхідності регулювати вплив класу черги на рівень якості обслуговування QoS за рахунок введених у структуру моделі умов і обмежень (5) з урахуванням коефіцієнту нормування $D$.

На рис. 8 наведено результати аналізу впливу завантаженості інтерфейсу на середню затримку пакетів для умов, при яких у сформовані на інтерфейсі 
маршрутизатора пріоритетні черги надходить трафік з асиметричною структурую для наступних вихідних даних:

- $M=4$ - загальна кількість організованих на інтерфейсі черг;

- $N_{A F 13}=8$ - кількість потоків пакетів з кодом подя DSCP AF13;

- $N_{A F 31}=4$ - кількість потоків пакетів з кодом поля DSCP AF31;

- $N_{A F 41}=4$ - кількість потоків пакетів з кодом подя DSCP AF41;

- $N_{E F}=4$ - кількість потоків пакетів з кодом поля DSCP EF;

- $b=100$ 1/с - пропускна здатність інтерфейсу маршрутизатора ТКМ.

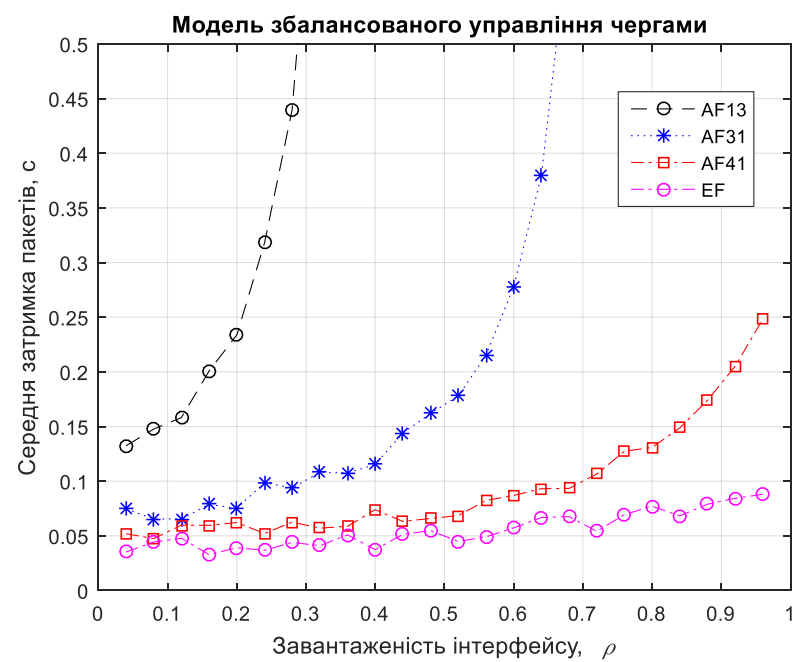

a)

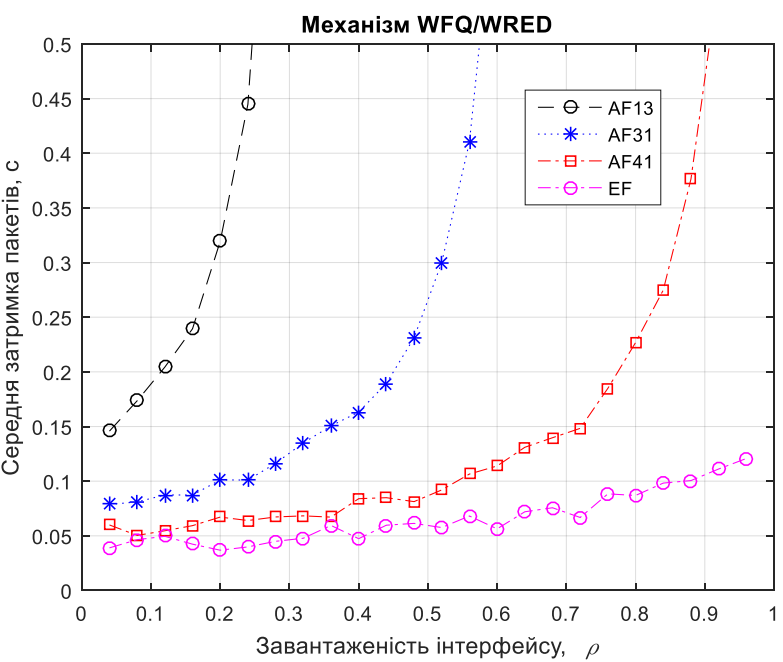

б)

Рuc. 8. Аналіз впливу завантаженості інтерфейсу на середню затримку пакетів при генерації асиметричного трафіка з різними значеннями коду поля DSCP та зростанні кількості низькопріоритетних потоків $\left(N_{A F 13}=8\right)$ для моделі збалансованого управління чергами (а) та механізму WFQ/WRED (б)

На рис. 9 показано результати дослідження випадку, при якому трафік асиметричної структури має наступні вихідні дані:

- $M=4$ - загальна кількість організованих на інтерфейсі черг;

- $N_{A F 13}=15$ - кількість потоків пакетів з кодом поля DSCP AF13;

- $N_{A F 31}=4$ - кількість потоків пакетів з кодом поля DSCP AF31;

- $N_{A F 41}=4$ - кількість потоків пакетів з кодом поля DSCP AF41;

- $N_{E F}=4$ - кількість потоків пакетів з кодом поля DSCP EF;

- $b=100$ 1/с - пропускна здатність інтерфейсу маршрутизатора ТКМ.

Із рис. 8 та рис. 9 можна зробити висновок, що при збільшенні асиметрії трафіка, яка проявлялась у зростанні кількості низькопріоритетних потоків порівняно з більш пріоритетними, використання механізму WFQ призводило до суттєвого перерозподілу канального ресурсу. Пропускна здатність інтерфейсу маршрутизатора більш ін- 
тенсивно виділялася низькопріоритетним потокам, що призводило до недоотримання канального ресурсу пріоритетними чергами (потоками). Це проявдялось у суттєвому зростанні середніх затримок пакетів з пріоритетами EF та AF41.

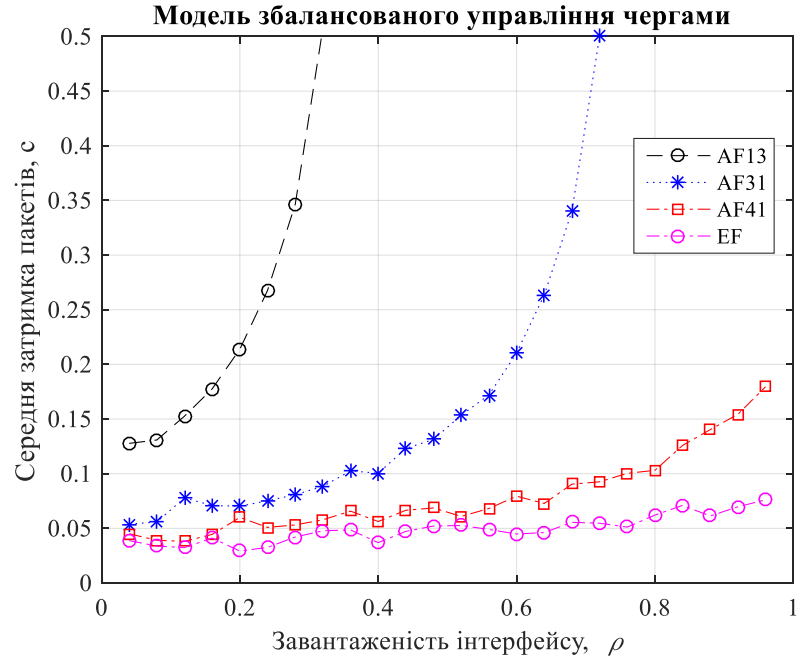

a)

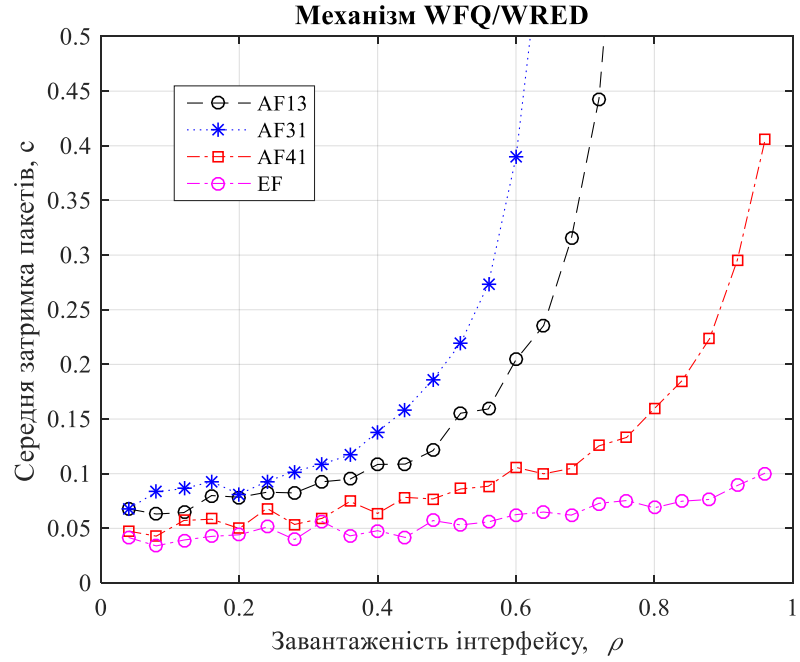

б)

Puc. 9. Аналіз впливу завантаженості інтерфейсу на середню затримку пакетів при генерації асиметричного трафіка з різними значеннями коду поля DSCP та зростанні кількості низькопріоритетних потоків $\operatorname{AF13}\left(N_{A F 13}=15\right)$ для моделі збалансованого управління (а) та механізму WFQ/WRED (б)

Використання запропонованої моделі збалансованого розподілу пропускної здатності інтерфейсу (1)-(8) дозволило більш раціонадьно розподілити канальний ресурс між потоками та чергами різних класів та пріоритетів. Цей факт дав мождивість покращити середню затримку пакетів для високопріоритетних потоків EF, AF41-AF43 у порівнянні з використанням механізму WFQ:

- на $12-17 \%$ - в області середньої $(0,55 \leq \rho \leq 0,8)$ завантаженості інтерфейсу маршрутизатора;

- на $22-25 \%$ - в області високої $(0,85 \leq \rho \leq 0,95)$ та критичної $(\rho \geq 0,96)$ завантаженості інтерфейсу маршрутизатора.

Для аналізу впливу завантаженості інтерфейсу на середню затримку пакетів досліджувався випадок (рис. 10), при якому у сформовані на інтерфейсі маршрутизатора телекомунікаційної мережі пріоритетні черги надходив трафік із наступною асиметричною структурую:

- $M=4$ - загальна кількість організованих на інтерфейсі черг;

- $N_{A F 13}=4$ - кількість потоків пакетів з кодом поля DSCP AF13;

- $N_{A F 31}=4$ - кількість потоків пакетів з кодом поля DSCP AF31;

- $N_{A F 41}=4$ - кількість потоків пакетів з кодом поля DSCP AF41;

- $N_{E F}=8$ - кількість потоків пакетів з кодом поля DSCP EF;

- $b=100$ 1/с - пропускна здатність інтерфейсу маршрутизатора ТКМ. 
Як можна побачити на рис. 10, у разі збільшення кількості високопріоритетних потоків EF механізм WFQ значно обмежує канальний ресурс, що виділяеться для низькопріоритетних черг. Тому, за анадогією до прикладів, які наведені на рис. 8 та рис. 9, для забезпечення диференціації обслуговування потоків пакетів із різними QoS-вимогами також доцільно використовувати запропоновану модель (1)-(8).

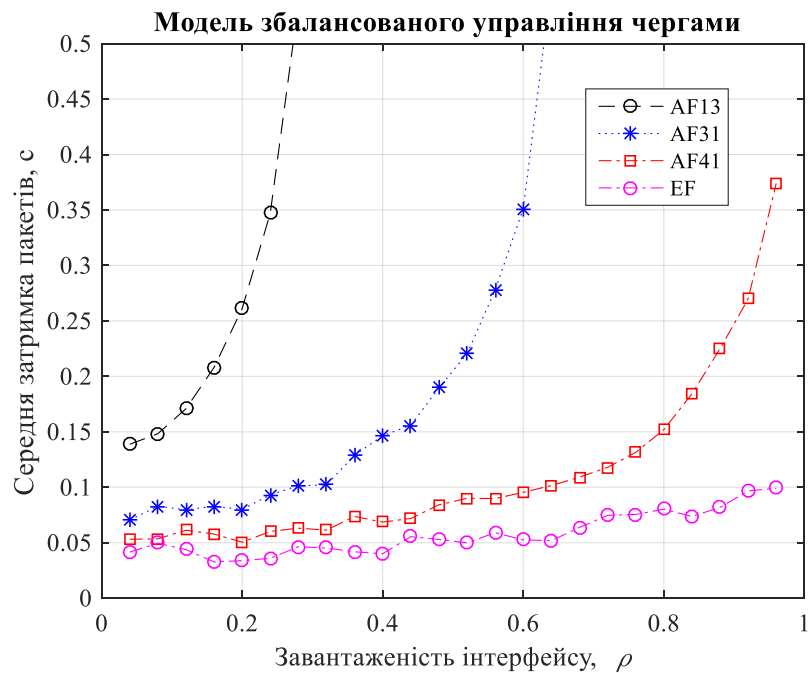

a)

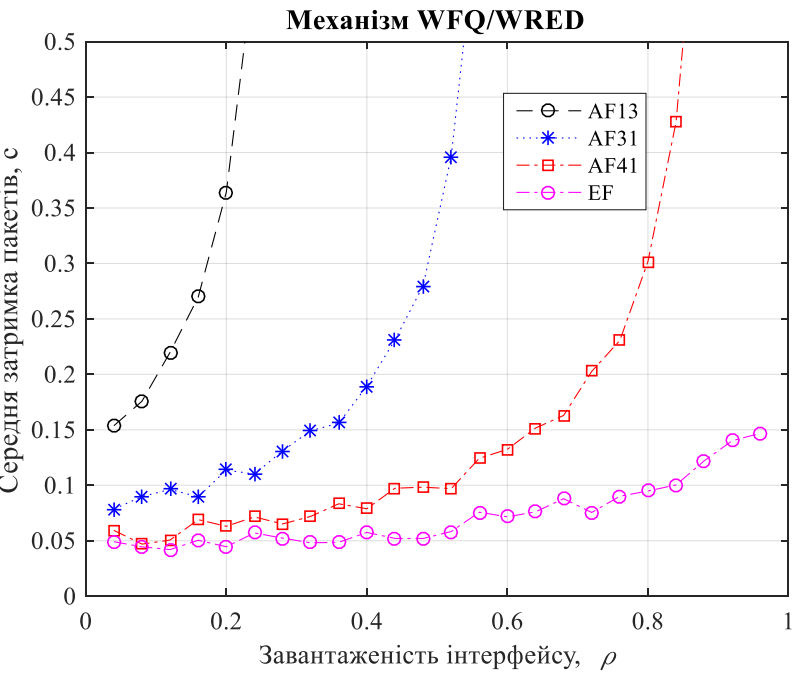

б)

Puc. 10. Аналіз впливу завантаженості інтерфейсу на середню затримку пакетів при генерації асиметричного трафіка з різними значеннями коду поля DSCP та зростанні кількості високопріоритетних потоків ЕF для моделі збалансованого управління (а) та механізму WFQ/WRED (б)

За результатами проведеного дослідження (рис. 10), вдалося підтвердити ефективність запропонованої в межах методу активного управдіння чергами моделі збалансованого розподілу пропускної здатності інтерфейсу маршрутизатора ТКМ (1)-(8) 3 точки зору покращення показників середньої затримки пакетів для низькопріоритетних потоків AF11-AF13:

- на 8-12\% - в області середньої $(0,55 \leq \rho \leq 0,8)$ завантаженості інтерфейсу маршрутизатора TKM;

- на $16-19 \%$ - в області високої $(0,85 \leq \rho \leq 0,95)$ та критичної $(\rho \geq 0,96)$ завантаженості інтерфейсу маршрутизатора ТКМ.

Також у рамках експериментального дослідження проводилося порівняння рішень, отриманих у ході проведення лабораторного експерименту щодо впливу завантаженості інтерфейсу маршрутизатора TKM на ймовірність втрат пакетів для запропонованої моделі активного управдіння чергами (1)-(4), (9)-(11) та для механізмів WFQ/WRED, налаштованих на інтерфейсі маршрутизатора «за замовчуванням».

Результати проведених досліджень щодо впливу завантаженості інтерфейсу маршрутизатора ТКМ на ймовірність втрат пакетів при генерації симетричного трафіка з різними значеннями коду поля DSCP свідчать про те, що обидва із розглянутих підходів працюють адекватно, а характер збігу результатів їхньої роботи 
є схожим до наведеного на рис. 7 порівняння. Аналіз впливу завантаженості інтерфейсу на ймовірність втрат пакетів при генерації асиметричного трафіка наведено на рис. 11.

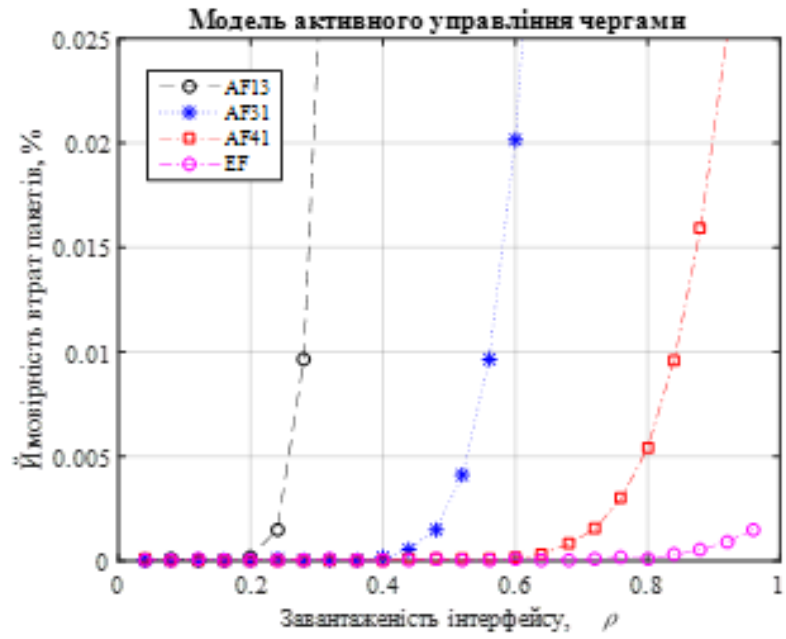

a)

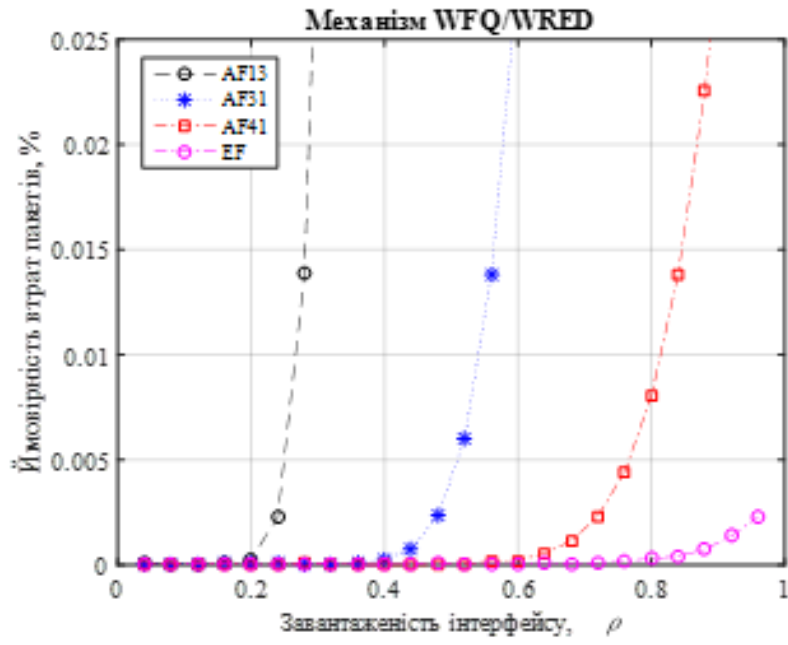

б)

Puc. 11. Аналіз впливу завантаженості інтерфейсу на ймовірність втрат пакетів при генерації асиметричного трафіка з різними значеннями коду поля DSCP та зростанні кількості низькопріоритетних потоків AF13 для моделі активного управління чергами (а) та механізму WFQ/WRED (б)

У разі генерації асиметричного трафіка та за умови, що кількість низькопріоритетених потоків пакетів AF13 зростає аналогічно прикладу, наведеному на рис. 8, використання моделі активного управління чергами (рис. 11) дозволяе забезпечити більш плавний характер відмов в обслуговуванні пакетам 3 високим пріоритетом. Тобто відмови в обслуговуванні будуть стосуватися усіх потоків пакетів, однак більшою мірою - 3 низькопріоритетних черг і меншою - з високопріоритетних.

На рис. 12 показано результати дослідження для прикладу, коли в структурі асиметричного трафіка збільшено кількість високопріоритетних потоків пакетів.

За результатами проведеного дослідження (рис. 11, рис. 12) установлено, що використання запропонованої моделі активного управління чергами (1)-(4), (9)-(11) дозводило знизити ймовірність втрат пакетів:

- на 7-12\% - для високопріоритетних потоків пакетів EF, AF41-AF43;

- на 10-17\% - для низькопріоритетних потоків пакетів AF11-AF13, в залежності від джерела асиметрії в структурі мережного трафіка.

3'ясовано, що рекомендована область застосування запропонованих моделей активного управління чергами та збалансованого розподілу пропускної здатності інтерфейсу ТКМ є область високої $(0,85 \leq \rho \leq 0,95)$ та критичної $(\rho \geq 0,96)$ завантаженості мережних інтерфейсів, особливо в умовах підвищеної динаміки зміни їх стану. В області низької завантаженості інтерфейсу маршрутизатора $(0 \leq \rho \leq 0,5)$ усі порівнювальні рішення забезпечували майже однаковий рівень якості обслуговування QoS. 


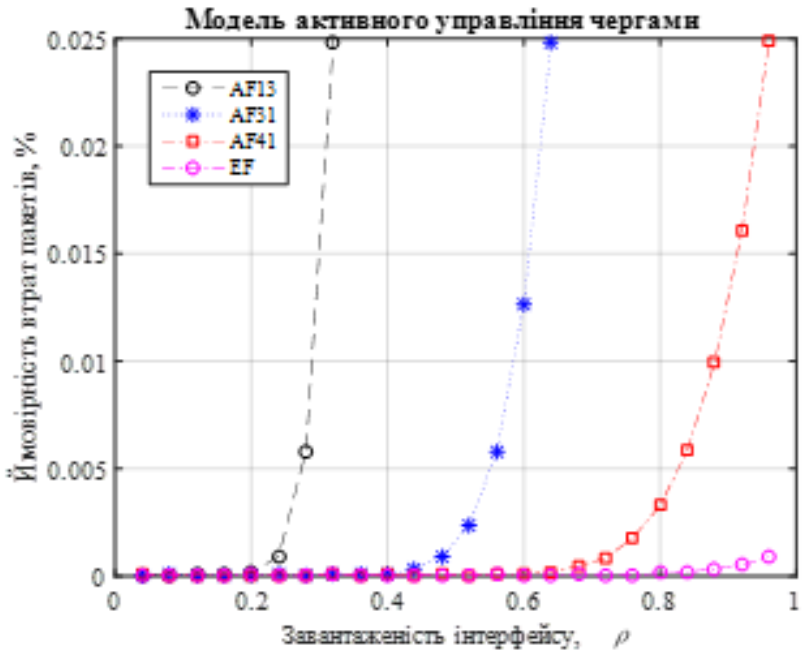

a)

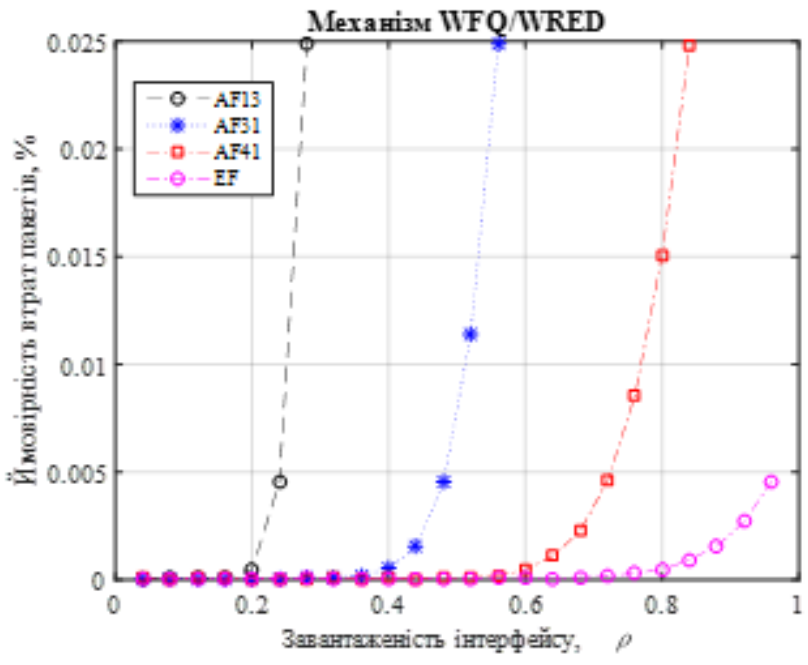

б)

Рuc. 12. Аналіз впливу завантаженості інтерфейсу на ймовірність втрат пакетів при генерації асиметричного трафіка з різними значеннями коду поля DSCP та зростанні кількості високопріоритетних потоків EF для моделі активного управління чергами (а) та механізму WFQ/WRED (б)

\section{VI. Рекомендації щодо практичного застосування методу активного управління чергами в ТКМ}

За результатами проведеного дослідження в межах лабораторного експерименту розроблено рекомендації щодо практичного застосування досліджуваного методу активного управління чергами на інтерфейсах маршрутизаторів телекомунікаційних мереж. Його алгоритмічна реалізація на практиці може бути покладена в основу перспективних механізмів управління чергами та пропускною здатністю інтерфейсів з метою підвищення рівня якості обслуговування в ТКМ у цілому.

На рис. 13 представлено функціональну схему інтерфейсів маршрутизатора TKM, де кожен $з$ фізичних інтерфейсів пов'язаний із апаратною (hardware queue) i програмною (software queue) системами черг. В апаратних чергах завжди «за замовчуванням» використовується механізм FIFO (Tx-ring). Конфігурація ж системних черг залежить від механізмів планування черг (WFQ, CBWFQ, LLQ) та активного управління чергами (WRED). Дані механізми починають працювати в той момент, коли апаратна черга заповнюється до своєї максимадьної ємності, а інтерфейс маршрутизатора починає зазнавати перевантаження. Тоді hardware queue сигналізуе програмній черзі щодо необхідності увімкнення будь-яких політик планування, наприклад, WFQ/LLQ/CBWFQ та активного управління чергами, наприклад, RED/WRED, що були налаштовані на інтерфейсі маршрутизатора раніше. 


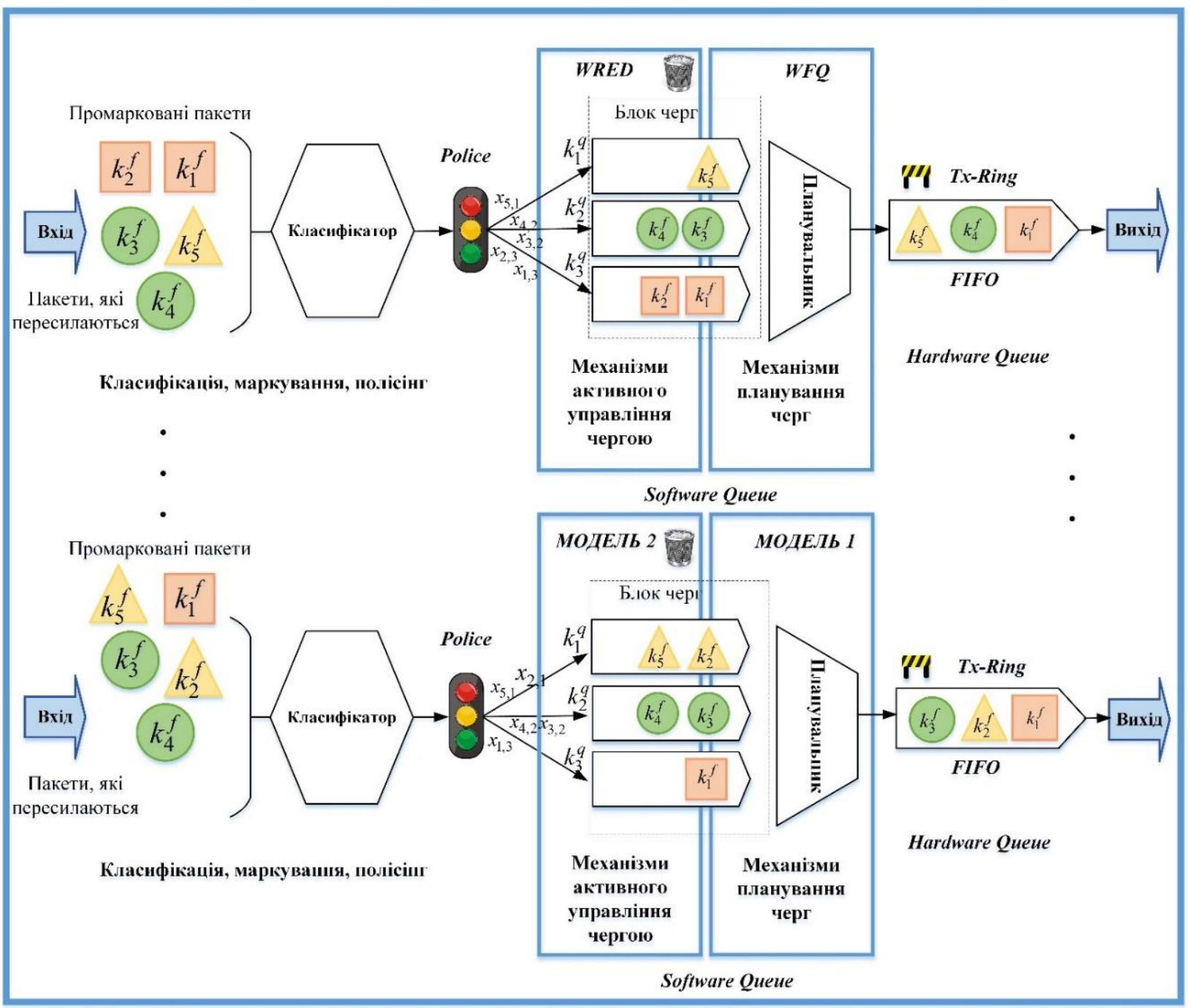

Рuc. 13. Принципи реалізації запропонованого методу та моделей управління чергами на інтерфейсах маршрутизаторів телекомунікаційних мереж

Отже, зважаючи на те, що процес формування черг на інтерфейсах маршрутизаторів ТКМ безпосередньо пов'язаний із їхнім перевантаженням чи високим рівнем завантаженості (більше 85-95\%), то рекомендованою областю використання отриманих рішень $є$ їхне застосування на інтерфейсах маршрутизаторів ТKM, в яких спостерігається нестача канального ресурсу. Так, модель збалансованого розподілу пропускної здатності інтерфейсу маршрутизатора TKM (1)-(8) рекомендовано застосовувати замість класичних механізмів планування черг FIFO, CQ, PQ, WFQ тощо. Це дозводить уникнути їхнього перевантаження за пропускною здатністю за рахунок більш гнучкого та раціонадьного розподілу канального ресурсу.

У разі ж перевантаження інтерфейсів доцільно використовувати модель активного управління чергами (1)-(4), (9)-(11) замість налаштованих «за замовчуванням» механізмів RED/WRED. Застосування даної моделі дає можливість завчасно обмежувати інтенсивність саме того потоку, що спричиняє перевантаження інтерфейсу. Тобто у разі перевантаження інтерфейсу маршрутизатора, відмови в 
обслуговуванні будуть носити збалансований характер: відмови стосуватимуться усіх потоків пакетів, однак більшою мірою - 3 низькокласових черг і меншою - 3 висококласових. Це дозволить забезпечити більш плавний характер відмов в обслуговуванні потоків пакетів замість стрибкоподібного.

На низько завантажених інтерфейсах або під час їхньої низької завантаженості (до 50-60\%) доцільно використовувати найпростіший механізм планування черг FIFO. Крім того, в області середніх навантажень при симетричній структурі мережного трафіка може застосовуватись й механізм WFQ.

\section{Висновки}

Експериментальне дослідження адекватності та оцінка ефективності запропонованих рішень щодо активного управдіння чергами та збалансованого розподілу пропускної здатності інтерфейсів маршрутизаторів ТКМ 3 точки зору основних показників якості обслуговування проводилося на базі лабораторії компанії Cisco Systems. Для навантажувального тестування для генерування та подальшого аналізування мережного трафіка використовувався пакет D-ITG. Для перевірки отриманих у ході застосування моделі збалансованого розподілу пропускної здатності інтерфейсів маршрутизаторів ТКМ (1)-(8) керуючих рішень щодо реалізації функцій розподілу канального ресурсу проводилося їхне порівняння 3 механізмами планування WFQ за середньою затримкою пакетів (рис. 7 - рис. 10). Для перевірки отриманих при застосуванні моделі активного управління чергами інтерфейсів ТКМ (1)-(4), (9)-(11) рішень щодо реалізації функцій активного управління чергами проводилося їхне порівняння з механізмами AQM WRED за ймовірністю втрат пакетів (рис. 11 - рис. 13). Усі дослідження проводилися на маршрутизаторах Cisco Systems серії 2801, коли зміні підлягали пропускна здатність інтерфейсу, кількість потоків пакетів, що надходили на його вхід, значення їхніх класів та інтенсивностей, кількість сформованих черг та їхня класифікація.

Результати проведеного дослідження підтвердили ефективність моделі збалансованого розподілу пропускної здатності інтерфейсу з точки зору покращення середньої затримки пакетів - від 12-17\% до 22-25\% для високопріоритетних потоків (EF, AF41-43) та від 8-12\% до 16-19\% - для низькопріоритетних потоків (АF11-13). Використання моделі активного управдіння чергами дозволило знизити ймовірність втрат пакетів на 7-12\% для високопріоритетних потоків (EF, AF41-43) та на 10-17\% для низькопріоритетних потоків (AF11-13).

Установлено, що рекомендована область практичного застосування пропонованих моделей управління чергами та пропускною здатністю - області високої завантаженості (більше 80-85\%) та перевантаження інтерфейсів маршрутизаторів ТКМ, особливо в умовах підвищеної динаміки зміни їхнього стану. 


\section{Список літератури:}

1. Аемешко А.В., Семеняка М.В., Али С. Али. Особенности проведения иабораторного эксперимента по исследованию процессов управления очередями в телекоммуникационных сетях. Цифрові технології. 2012. №10. С. 5-17.

2. Евсеева О. Ю. Методика экспериментального исследования методов управления трафиком в сети. Проблеми телекомунікацій. 2011. №3 (5). C. 89-104. URL: http://pt.nure.ua/wpcontent/uploads/2020/01/113_yevseyeva_experiment.pdf.

3. Семеняка М.В., Старкова О.В., Аемешко О.В. Методичні вказівки до иабораторних робіт 3 дисципліни «Системи комутації та розподілу інформації. Частина 2» для студентів денної форми навчання спеціальності 7.092401 - Телекомунікаційні системи та мережі. Харків: ХНУРЕ, 2014. 92c.

4. Иебеденко Т.М., Головешко М.В., Холодкова А.В. Дослідження методу активного управління чергами на інтерфейсах маршрутизаторів телекомунікаційних мереж. Системи управління, навігації та зв' язку. 2019. №4 (56). C. 57-62. DOI:10.26906/SUNZ.2019.4.057.

5. Аебеденко Т.М., Мокряк А.А., Симоненко О.В., Черкасов А.В., Власенко А.О. Вдосконалення та дослідження методу збалансованого управління чергами на інтерфейсах маршрутизаторів телекомунікаційної мережі. Проблеми телекомунікацій. 2018. №2 (23). C. 62-74. URL: http://pt.nure.ua/wp-content/uploads/2020/01/182_lebedenko_queue.pdf.

6. Lebedenko T. Method of Scheduling and Active Queues Management on Routers Interfaces of Telecommunication Networks. Innovative Technology and Scientific Solutions for Industries. 2019. 2 (8). P. 54-61. DOI: 10.30837/2522-9818.2019.8.054.

7. Яемешко А.В., Семеняка М.В. Модель и метод предотвращения перегрузок с активным управлением длинной очереди на узлах телекоммуникационной сети. Проблеми телекомунікацій. 2014. №9 (14). С. 15-25. URL: http://pt.nure.ua/wp-content/uploads/2020/01/ 142_lemeshko_aqm.pdf.

8. Єременко О.С., Лебеденко Т.М., Каплун С.А., Костенко В.О. Імітаційна модель функціонування інтерфейсів маршрутизаторів телекомунікаційних мереж, побудована з використанням пакета Simulink. Проблеми телекомунікацій. 2017. №2 (21). C. 61-72. URL: http://pt.nure.ua/wp-content/uploads/2020/01/172_yeremenko_simulink.pdf

9. Avallone S., Guadagno S., Emma D., Pescapè A., Ventre G. D-ITG Distributed Internet Traffic Generator. Quantitative Evaluation of Systems (QEST'2004): Proceedings of the First International Conference, (Enschede, The Netherlands, 27-30 September 2004). Enschede, 2004. IEEE, 2004. P. 316317. 